農村醫學・地域保健學會誌: 第32券 第3號(2007年 12月)

J Agri Med \& Community Health 2007; 32(3) : 139 153

$$
\text { 농작업재해감시체계개발 }
$$

고재우, 권순찬, 김경린리, 이경숙ㄹ, 장은철2), 권영준(3), 류승호), 이수진, 송재철

한양대학교 의과대학 산업의학교실, 농촌진흥청 농촌자원개발연구소1) 순천향대학교 의과대학 산업의학교실2), 한림대학교성심병원 산업의학관, 강북삼성병원 산업의학관)

\title{
A study on the Development of Surveillance System for Agricultural Injuries in Korea
}

\author{
J ae-Woo Koh, Soon-Chan Kwon, Kyung-Ran Kim¹, Kyung-Suk Le $e^{1)}$, \\ Eun-Chul J ang'), Young-J un Kwon ${ }^{3)}$, Seung-Ho Ryu'4), Soo-J in Lee, Jae-Chul Song \\ Department of Occupational and Environmental Medicine, College of Medicine, Hanyang University \\ Rural Resources Development Institute, NIAST, RDA, Koreal ${ }^{\text {, }}$, Department of Occupational and \\ Environmental Medicine, College of Medicine, Soonchunhyang University ${ }^{2}$, Department of \\ Occupational and Environmental Medicine, Hallym University Sacred Heart Hospital ${ }^{3)}$
} Department of Occupational Medicine, Kangbuk Samsung Hospital ${ }^{4}$

$$
=A B S T R A C T=
$$

Injury in agriculture is a serious public health issue with a major impact on the lives of Korean farmers. It is one of the leading causes of death and is also a major cause of longand short-term disability. In 2001, the social cost of one accident in agricultural machinery was estimated as 97.7-97.8 million won that is 4 fold of farm household income in Korea.

Effective prevention and control of injuries requires a system of surveillance that monitors the incidence of injuries, their causes, treatment and outcomes. This requires an integrated system of data collection, analysis and interpretation and communication. Creating effective injury surveillance system in Korea requires to establish a framework for a national agenda. Discussions regarding the development of the framework should address, but not be limited to issues related to Data Holdings and Linkages; Capacity and Skills; Communication; Interconnection; and Surveillance Products. Ideally, an injury surveillance system would meet the information requirements across all sectors, while allowing each to have the ongoing information it needs for its policy and programming needs.

This study was carried out to develop a surveillance system of agricultural injuries in Korea. Study subjects were residents who lived in a typical agricultural area (Y angpyung area in Kyung-gi province). The main data sources were reports of village headmen, compared with data of 'National Emergency Management Agency', 'National Health Insurance Corporation', 'Insurance of National Agricultural Cooperative', and 'Emergency Medical Centers'. Each data were reviewed to validate the strengths and weaknesses.

Key words : Injury, A griculture, Surveillance system

* 교신저자: 송재철, 서울특별시 성동구 행당동 17번지, 전화: 02-2220-0663

E-mail: jsong@hanyang.ac.kr 


\section{서 론}

농업은 위험한 직업군의 하나로 산업재해 문제의 주요 관심대상 산업이다[1]. 특히 농기 계보급 확대 등 농업여건의 변화로 인한 작업 부담강화와 위험한 작업환경의 증가로 농업인 의 직업성 재해 발생이 증가하고 있다[2]. 특 히 손상이 중요한 농업인의 건강문제로 대두 되고 있으나[3-8], 우리나라의 경우 발생양상 이나 원인적 접근에 필요한 체계가 없어 실태 조차 제대로 파악되어 있지 않다.

직업성 질환의 경제적 손실 규모는 11 조 4천 만 원(산재보상금의 4배)으로 추정되며, 농업 에서의 재해율은 전체 산업 평균 재해율의 1.4 배나 되기 때문에 농업에서의 손실 규모도 상 당할 것으로 추정된다[9]. 더욱이 노동부에서 발표하는 산재요양 자료는 기업영농 또는 농 업과 관련된 제조업종이 대부분을 차지하기 때문에 실제 경작 농업인의 재해율을 제대로 반영한다고 할 수 없다. Kang[10]의 연구에 의 하면, 농기계사고 건당 총 비용은 9770-9776원으로 농가소득의 4 배에 해당한다. 그동안 4 대 사회보장제도 중 산재관리체계에서 농업인 은 제외되어 왔으나, 2004년 6월에 시행된농 림어업인삶의질향상및농산어촌지역개발촉진에 관한특별법』에서 농림어업인 업무상재해 예방, 치료, 관리에 관한 국가지원을 구체적으로 명 시함으로써 농업인의 재해에 대한 관심이 증 가하고 있다.

외국에서는 농작업손상에 대한 다양한 역학 연구가 수행되고 있으며[11-29], 국가적인 농 작업손상 감시체계를 운영하고 있다. 외국의 농작업손상 감시체계 현황을 보면, 캐나다에서 는 1996년부터 국가차원의 감시체계인 Canadian Agricultural Injury Surveillance Program(CA ISP을 운영하고 있고, 미국에서는 치명적인 손상과 치명적이지 않은 손상으로 나누어 Census of $F$ atal Occupational Injuries(CF Of) Survey of Occupational Injuries and IIInesses(SOII)를 운영하고 있으며, 영국에
서는 보건안전청(Health and Safety Executive, $\mathrm{HSE}$ ) 주관으로 농작업손상 감시체계를 운영 하고 있다. 반면, 국내에서는 농기계사고에 대 한 몇몇 조사가 이루어졌을 뿐[30-33], 전반적 인 농작업재해 실태조사 및 국가적 통계가 부 족한 실정이다.

따라서 이번 연구는 농작업과 관련된 손상 을 파악할 수 있는 감시체계 모델을 개발하여 일부 농촌지역을 대상으로 시범운영을 함으로 써 감시자료 수집체계를 평가하고 우리 실정 에 맞는 농작업재해 감시체계의 모델을 제시 하고자 하였다.

\section{대상 및 방법}

\section{1. 감시모델 설계}

1) 설계의 고려사항

감시체계의 대상 질병은 보건학적 중요성을 고려하여 선정한다. 첫째, 다빈도 질병, 중증 질병, 비용절감효과, 예방 가능한 질병, 주위에 대한 영향을 고려한다. 둘째, 시범감시체계 지 역을 선정하는데 있어 유해요인 폭로지역, 즉 농촌지역에 대한 지역사회 및 보건기관의 협 조, 접근성 등을 고려한다. 셋째, 발생률 등 목 적에 부합하는 지표를 설정하고 관련요인(농 작업요인, 비농작업요인)을 파악할 수 있도록 한다.

2) 농작업재해 감시체계의 방법론 개발 감시 자료는 2 차 자료(국민건강보험자료, 사 망원인통계자료 등)를 이용한 경우와 농작업 재해 현황을 통해 직접 확인된 자료를 이용한 경우가 있으나, 실제로 두 가지 모두를 활용해 야 할 가능성이 높다.

\section{3) 환례의 보고 형태}

환례의 보고 형태는 개별 환례가 발생할 때 마다 보고하거나 일정기간의 총 환례보고, 또 는 집단으로 유행할 경우 보고할 수 있다. 농 작업재해의 경우 일정기간의 총 환례를 보고 
하는 방식이 적절한 방법일 것이다.

4) 지역관리체계의 구성

지역의 농작업 및 보건관련기관 및 인력의 적극적 참여와 관리를 위하여 지역관리체계를 구성하여야 한다.

5) 보고원 네트워크 구성

자료를 보고할 보고자 또는 보고기관은 마 을주민, 병의원, 응급실, 응급의료센터, 119 소 방서, 보건소, 보건지소, 보건진료소, 국민건강 보험공단, 농협공제조합이 대상이 된다.

\section{6) 시범운영}

시범운영은 감시체계의 목표, 설계, 운영상의 문제점을 도출하기 위한 단계이다. 이 과정의 평가를 통해 달성 가능한 목표를 재설정하고, 발견된 문제점을 수정하여 우리나라의 실정에 맞는 감시체계 모델을 개발하고 궁극적으로 안정된 감시체계를 정착시킬 수 있다.

\section{7) 감시체계의 평가}

시범운영을 통해 얻어진 자료에 대하여 산 업의학, 역학 등 관련전문가의 토론을 통하여 각 자료원의 질을 평가한다.

\section{2. 감시체계 시범운영}

1) 감시체계 방법론 개발

감시체계는 자료수집 기전에 따라 수동적 감시와 능동적 감시로 이루어지는데, 이번 시 범운영에서는 마을주민대표(이장)가 마을주민 들이 작성한 감시보고서를 직접 수거하여 보 고하는 수동적 감시를 중심으로 구성하였고, 자료의 완결성을 높이기 위해 국민건강보험, 산업재해보상보험, 사망원인통계, 의무기록, 구 급활동일지, 농협공제(농업인안전공제, 농기계 종합공제)자료와 같은 기존의 자료를 이용하 는 능동적 감시를 함께 활용하였다.

2) 대상 질병의 선정 및 환례정의

대상 질병으로는 손상, 중독 및 농작업 관련 다빈도 상병을 고려하여 2004년 1월 1일부터 2004년 12월 31일까지 1년 동안 농작업과 관련 하여 발생한 손상으로 한정하였다. 그리고' 농 기계(경운기, 트랙터, 콤바인 등)나 농기구(손 연장, 파워연장 등)에 의해 손상을 받는 경우 또는 작업장에서 추락/전도하거나, 가축에게 물리는 등 농작업 도중 발생하는 모든 농작업 손상 중 1 차 의료기관 이상에서 진료를 받은 자'를 환례로 정의하였는데 이는 다른 감시체 계를 통해 확보한 자료들과 비교 가능하도록 하기 위함이다. 농작업 도중 발생하는 모든 농 작업 손상의 범위는 표 1과 같다.

농작업과 관련하여 교통수단 이용 시 발생

표 1 농작업재해 감시체계 대상 재해

\begin{tabular}{ll}
\hline \hline 손상원인 & \multicolumn{1}{c}{ 손상기전 } \\
\hline 농기계 $^{*}$ & 기계의 전복, 기계 위에서의 추락, 기계 사이에 낌, 기계에 깔림, \\
& 기계 회전부에 말림 등에 의한 손상, 자동차와 충돌 등 \\
농기구 $^{\dagger}$ & 기구에 의한 자상, 열상 등 \\
추락/전도 & 작업장 바닥에 쓰러짐, 걸려서 넘어짐, 높은 곳, 나무에서 떨어짐 \\
가축 & 물림, 차임, 가축위에서의 추락 \\
중독 & 농약, 기타화학약품, 액체(비화학약품)에 의한 손상 \\
기타 & 고정되거나 움직이는 물체에 의한 손상, 전기, 벌레/곤충 \\
\hline
\end{tabular}

* 농기계 : 경운기, 트랙터, 콤바인, 동력 예취기, 교통수단 등 농작업에 사용되는 기타 기계들

† 농기구 : 파워연장, 손연장 및 농기계를 제외한 특이한 장비들 
한 손상의 경우 농기계에 의한 손상에 포함시 켰으며, 농기계로 이동시 도로 등에서 자동차 와의 충돌과 같은 교통사고 등도 손상에 포함 하였다.

\section{3) 대상지역의 선정}

협조정도, 접근도 등을 고려하여 감시체계 시범지역을 선정하였다. 시범지역으로는 농업 인 명부에 의한 농민분포가 $87.7 \%$ 를 차지하고 감시체계 시범운영에 대한 마을주민대표의 지 지가 높았던 경기도 양평군의 일개면 지역을 선정하였다.

4) 조사내용의 확정

농작업재해 감시체계를 통하여 원인 규명을 할 수 있도록 조사 내용은 표 2와 같이 구성 하였다.

\section{5) 환례보고방법}

보고 방법은 마을주민대표가 수거한 감시보 고서를 우편으로 보고하는 방식을 주로 활용 하였고, 보고의 누락이 발생하지 않도록 보고 가 늦는 경우, 직접 시범지역의 마을주민대표 를 방문하여 감시보고서를 수거하였다. 특히, 재해자의 감시보고서 작성이 미비한 경우 재 해자와 직접 전화통화를 하여 완성하였다.

\section{6) 보고원 네트워크 구성}

지역의 실정에 밝고 병원 치료를 받을 정도 의 손상을 입은 지역주민에 대한 파악이 비교 적 쉬운 마을주민대표를 농작업재해 감시체계 의 핵심적인 보고원으로 선정하였다. 환례정의 에 따라 보건소, 병의원을 포함한 응급의료센
터를 중요한 보고원으로 선정하였고, 농작업재 해가 발생할 경우 응급상황이 많이 발생할 수 있기 때문에 가장 신속하게 대응할 수 있는 119 소방서 역시 중요한 보고원으로 선정하였 다. 그리고 농작업재해의 규모와 심각성을 파 악할 수 있는 국민건강보험공단(건강보험자 료), 농협공제(농업인 안전공제자료, 농기계 종 합공제자료), 산업재해보상보험(산재보상자 료), 통계청(사망원인통계자료)을 보고원으로 선정하였다. 이번 연구에서 사망원인통계자료 는 환례정의에서 벗어나므로 제외하였다.

7) 보고원 교육

2005년 9월 공청회를 마련하여 마을주민대표 에 게 농작업재해에 대한 기본개념과 심각성을 교육하였고, 수차례 마을주민대표회의를 통해 농작업재해에 대한 환례 정의와 보고방법을 교육하고 감시보고서작성에 대한 실습을 실시 하였다. 또한 안내 자료를 배포하여 부가적인 교육효과를 도모하였다.

\section{8) 감시체계 평가}

설계된 감시체계를 바탕으로 2004년 1월 1일 부터 2004ㅕㅕㄴ 12월 31일까지 1년 동안 발생한 농작업재해 발생정도를 조사하여 자료원의 성 격을 파악하고 완결성, 신뢰성, 정확성을 평가 하였다. 농작업재해 감시체계에 대한 평가내용 은 표 3과 같다.

결 과

\section{1. 농작업재해 감시체계 시범운영결과}

이번 시범운영에서는 마을주민대표, 응급의

표 2. 농작업재해 감시체계의 조사내용

\begin{tabular}{ll}
\hline \hline 분류 & \multicolumn{1}{c}{ 조사내용 } \\
\hline 인구학적 특성 & 나이, 성별, 거주지 \\
농작업 특성 & 농작업 분류, 작업량, 농업인 분류 \\
손상 및 중독 특성 & 손상 원인, 손상 부위, 손상 정도 \\
의료 이용 특성 & 이동방법, 치료형태, 치료 의료기관, 의료비, 보상 여부 및 수준 \\
\hline
\end{tabular}


표 3. 농작업재해 감시체계에 대한 평가내용

평가의 착안점 및 척도

착안사항 척도(점수)

- 농업인 $\mathrm{DB}$ 구축 여부

- 농업인 재해 현황 파악

• 농업인 재해 정도 비교

- 농작업 재해 지역 조사

- 재해 감시체계 방법론

- 재해감시체계 시범운영 및 평가

- 표준 감시체계안 제시

- 재해감시체계를 통해 재해 현황 파악 여부
농업인 DB 대표성

농업인 재해 현황

농업인 재해의 산업별 비교

재해 지역조사 방법의 타당성

지역조사 결과의 타당성

재해감시체계 방법론의 타당성

감시체계 결과의 타당성

표준 감시체계안의 적용 가능성

감시체계 운영 및 결과의 타당성
료센터, 119소방서, 국민건강보험이 주된 보고 원이었다. 개인별 인적사항에 대한 구체적인 정보를 알 수가 없었던 국민건강보험자료를 제외한 마을주민대표, 응급의료센터, 119소방서 에 의한 농작업재해 11건에 대해서 각 보고원 별로 도식화하였다. 마을주민대표에서 보고된
환례가 11 건, 응급의료센터에서 보고된 환례가 1건, 119 소방서에서 보고된 환례가 1건이었다. 마을주민대표가 보고한 환례 11건 중 10건은 마을주민대표를 통해 보고되었고, 1건은 응급 의료센터 의무기록을 역추적 하여 보고되었다 (그림 1).

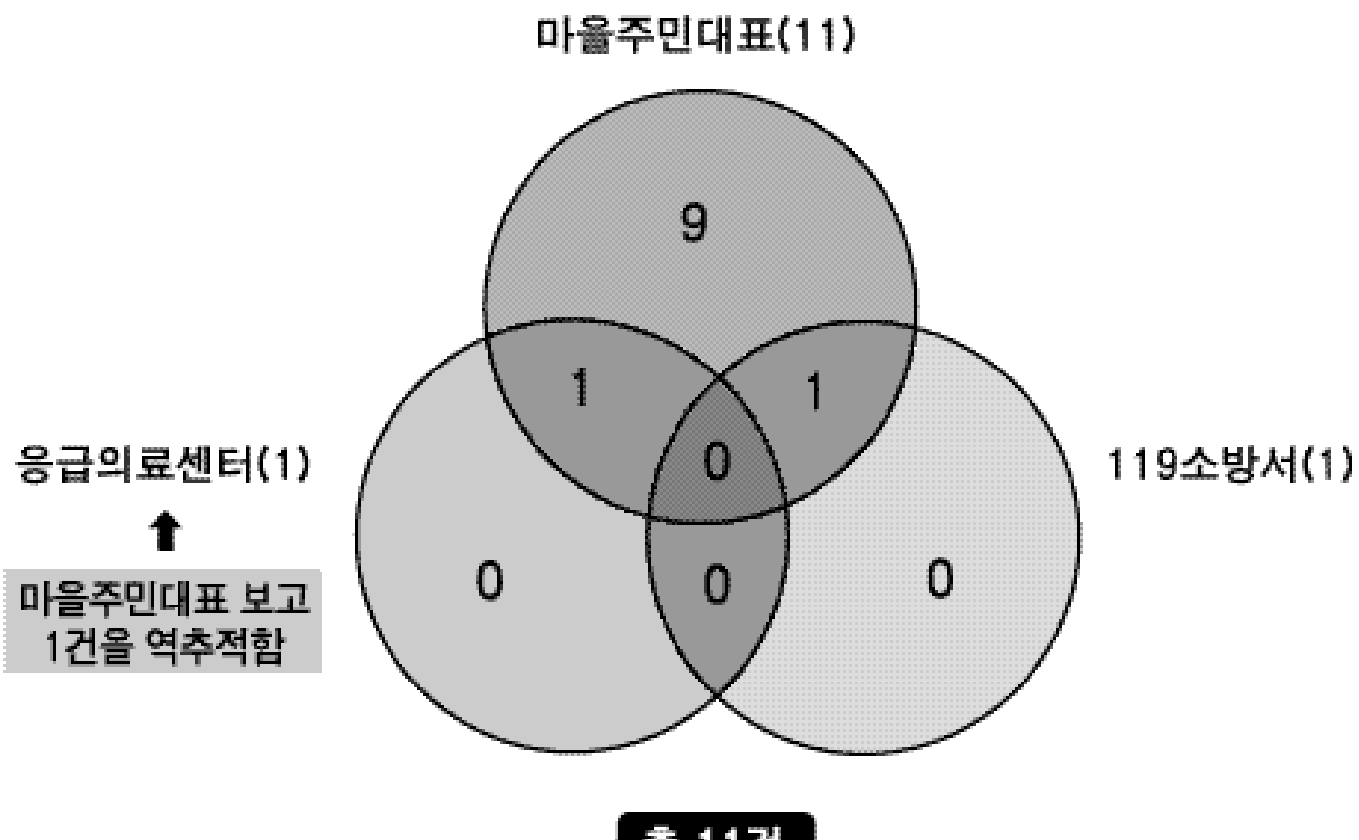

총 11건

그림 1 보고원별 농작업재해 환례 다이어그램 
1) 마을주민대표로부터 수집된 감시보고서 분석

시범지역은 농업인 비율이 $87.7 \%$ 로 상당히 높은 지역이다. 시범지역 일개면 20개 리 중 12 개 리 총 2,700ㅕㅕㅇㅇㅔ 대해서 2005년 11월부터 2006젼 3월까지 마을주민대표를 통해 농작업 관련 손상에 관한 조사가 이루어졌고, 총 328 건의 보고서가 취합되어 응답률은 $12.1 \%$ (328/2,700)다. 응답자의 평균 나이는 60( \pm 11.6$)$ 세였고, 성별은 남자가 $79.6 \%$ 로 대부 분을 차지하였고, 농사경력은 약 32( \pm 15.1$)$ 년 이었다. 논농사가 $87.5 \%$, 밭농사가 $76.6 \%$ 로 대 부분을 차지하였고, 축산업 $23.8 \%$, 비닐하우스 $19.5 \%$, 특용작물 $3.7 \%$, 과수원 $1.8 \%$ 순이었다 (중복허 용). 2004년 농작업 재 해율 은 $3.4 \%$ ( $11 / 328$ 난다옹작업재해 11 건 중 농기계 손상이 8건, 추락/전도가 3건이었고, 손상기전 으로는 기계의 전복에 의한 것이 4건, 회전부 에 말린 것이 3건, 작업장에서 미끄러진 것이 3건, 농기계에서 떨어진 것이 1건이었다. 손상 원인 농기계로는 경운기 5건, 트랙터 1건, 동력 예취기 1건, 가래떡기계가 1건이었다. 병원이송 수단으로는 자가용/택시가 7건, 119 구급차 3건, 버스가 1건이었다. 입원치료가 8건, 통원치료가 3건이었고, 평균 입원기간은 36( \pm 27.0$)$ 일이었
으며, 평균 본인부담금은 $122( \pm 102.3$ )ㅏㅏㄴ원이었 다. 사고부위로는 하지가 7건으로 가장 많았고, 상지 2건, 엉덩이 2건 순이었다. 사고내용으로 는 골절이 5건으로 가장 많았고, 염좌 3건, 열 상 2건, 좌상 1건 순이었다. 월 별 농작업재해 분포를 보면 5월과 6월에 각각 2건, 11월에 1 건이었고, 그 외 6건은 기억하지 못하였다(표 4) .

\section{2) 응급의료센터 의무기록 분석}

시범지역의 응급의료센터인 양평길병원을 선정하고 양평길병원의 협조를 얻어 2004ㅕㅕ 1 월 1일부터 12월 31일까지 1년 동안 응급실에 방문한 환자 중 손상코드인 T-codeㄹ S-code 에 해당하는 총 98 건을 선별하였다. 감시체계 내의 의료진 2명이 선별된 손상환자에 대한 입원 의무기록을 열람하여 미리 만들어 둔 조 사양식에 기입하고, 농작업재해 여부를 판별하 였다. 의무기록에서 사고기전 및 사고원인을 정확히 알 수 있는 경우 확진환례로 정의하였 고, 사고기전만 알고 정확한 사고원인을 알 수 없는 경우 가능 환례로 정의하였다. 농작업재 해 확진 환례 15 건, 농작업재해 가능 환례 7건 에 대한 총 22건에 대해 분석하였다.

손상원인으로는 농작업재해 22건 중 농기계

표 4. 농작업관련 손상사례 요약

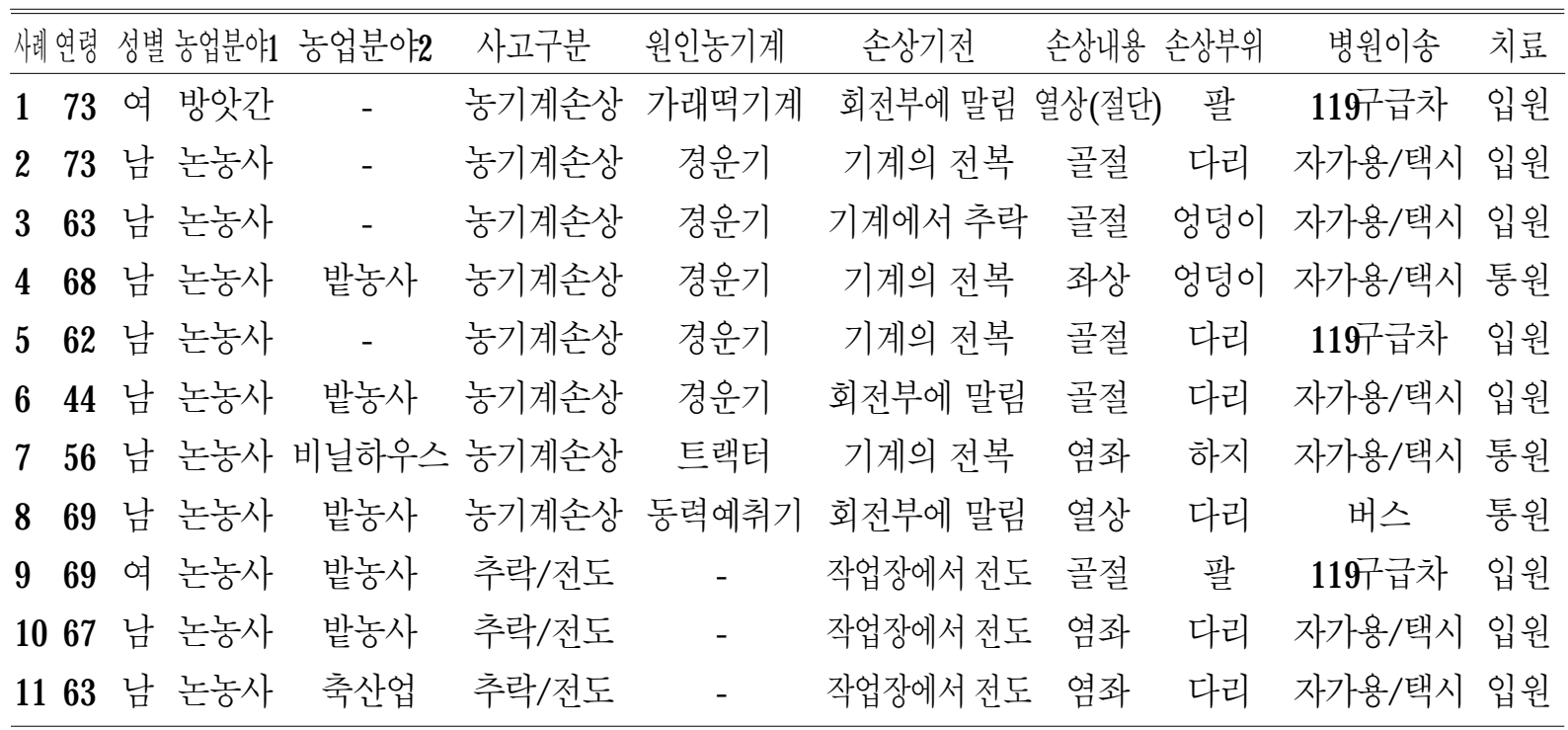


손상이 13건, 추락/전도가 5건이었고, 그 외 날 아오는 물건에 맞은 경우가 3건, 농기구 손상 이 1건 순이었다. 추락/전도 5건 중 1건은 시 범지역에서 발생하였다. 손상기전으로는 전도 가 5건으로 가장 많았고, 기계에서 떨어진 경 우가 4건, 기계의 전복과 날아오는 물체에 맞 은 경우가 각각 3건, 사이에 낀 경우와 회전부 에 말린 경우가 각각 2건, 경운기와 충돌한 경 우, 자동차와 충돌한 경우 그리고 농기구에 의 한 손상이 각각 1 건이었다. 사고부위로는 상지 가 10 건(45.5\%)으로 가장 많았고, 하지가 5건, 흉부가 3건, 경부가 2건, 두안부와 전신이 각각 1건이었다. 사고내용으로는 골절이 13건 (59.1\%)로로 가장 많았고, 열상이 4건, 염좌가 3건, 좌상이 2건이었다. 손상원인 농기계로는 경운기가 6건으로 가장 많았고, 트랙터가 3건, 커터기가 1건 그 외 정확한 이름을 알 수 없 었던 농기계가 3건이었다. 월 별 농작업재해 분포를 보면 농번기인 5월부터 10월까지 6개 월 간 총 22 건 중 15 건(68.2\%)의 농작업재해가 발생하였다.

\section{3) 119 소방서 구급활동일지 분석}

경기도 양평군 소방서의 협조로 구급활동일 지 열람이 가능하였고, 사고 및 손상에 관련된 자료는 총 6건이었다. 이중 농작업손상과 관련 된 환례는 1건 뿐이었고, 그 외 5건은 약물중 독과 관련된 환례로 분석에서 제외되었다. 마 을주민대표가 보고한 감시보고서에 의하면 3 명이 119소방서를 이용하였다고 하였는데, 실 제로 1명만이 119구급차를 이용한 것으로 조 사되어 나머지 2명은 누락이 되었거나, 119 구 급차가 아닌 다른 교통수단을 이용했을 가능 성이 있다.

\section{2. 농작업재해 감시자료 수집체계의 평가}

시범운영의 결과를 바탕으로 첫째, 농작업재 해 감시체계 구축에 필요한 자료원들의 성격 을 파악하였다. 시범운영에서 주축을 이룬 마 을주민대표의 보고, 응급의료센터(의무기록),
119소방서(구급활동일지), 국민건강보험 자료 가 확보되었으며, 보건기관(보건소, 보건지소, 보건진료소), 농협공제(농업인 안전공제자료, 농기계 종합공제자료), 산업재해보상보험, 사 망원인통계 자료는 확보되지 않았다. 마을주민 대표는 농작업재해가 발생할 경우 가장 빠르 고 정확하게 보고할 수 있는 핵심적인 보고원 이지만, 보고자에 따라 보고의 질과 양에 대한 차이가 발생할 수 있다. 응급의료센터를 포함 한 의료기관은 의무기록 및 수진자료가 전산 화되어 있어 자료의 수집이 용이한 보고원이 며, 119소방서는 응급상황이나 손상환자 발생 시 가장 신속하게 대응할 수 있는 보고원이다. 이들이 작성하는 구급활동일지에는 사고의 전 반적인 내용 및 이용기관 이송 형태 등 감시 체계에 필요한 자료가 포함되어 있다. 국민건 강보험 자료는 개개인에 대한 손상 자료는 구 체적으로 얻기 힘들지만, 건강보험심사평가원 에서 확보한 수진 자료를 이용하여 손상데이 터베이스를 구축한다면 의료기관의 보고를 대 체할 수 있는 보고원으로 활용할 수 있고, 전 반적인 손상현황을 파악할 수 있다. 농업인만 을 대상으로 하는 보험 중 농업인 안전공제와 농기계 종합공제가 있는데, 이 보험은 재해 발 생 시 농어민에게 보상금을 지급하고 있어 농 작업재해 감시체계의 중요한 자료원이 될 수 있다. 하지만 현재 보장수준이 적어 가입률이 낮다는 한계가 있다. 산업재해보상보험은 산재 근로자와 그 가족의 생활을 보장해주는 의무 보험으로 산업재해보상 자료는 기업영농이나 농산물 가공 등의 사업장에서의 재해율을 평 가할 수 있다. 그러나 우리나라의 경우 대부분 이 자영농이기 때문에 활용가치가 떨어진다. 사망원인통계 자료는 사망원인서의 사망원인 을 기초로 생산되는 통계로 손상에 의한 사망 을 추정할 수 있는 보고원이지만, 이번 연구에 서는 환례정의에서 벗어나므로 제외하였다(표 $5)$.

둘째, 농작업재해 감시체계 자료원에 대한 완결성 평가와 감시 자료의 신뢰성 및 정확성 
표 5. 보고원별 자료의 특성

\begin{tabular}{lcccc}
\hline \hline & 시의 적절성 & 완결성 & 포괄성 & 접근성 \\
\hline 마을주민대표 & 상 & 상 & 중 & 상 \\
응급의료센터 & 상 & 중 & 중 & 중 \\
119 소방서(소방방재청) & 상 & 중 & 중 & 상 \\
보건기관(병원 등) & 중 & 중 & 중 & 하 \\
국민건강보험 & 하 & 하 & 상 & 중 \\
농업인 안전공제 & 중 & 중 & 중 & 상 \\
농기계 종합공제 & 중 & 중 & 중 & 상 \\
산업재해보상보험 & 하 & 중 & 중 & 중 \\
사망원인통계 & 하 & 하 & 중 & 중 \\
\hline
\end{tabular}

확보를 위해서는 국민건강보험 자료의 활용이 요구된다. 재해가 발생하여 자가 치료를 받는 경우를 제외하고는 궁극적으로 재해가 발생한 환자는 의료기관의 진료를 받을 수밖에 없으 며 사고 발생일과 치료내역(손상부위, 치료비 용)을 정확히 파악할 수 있는 국민건강보험 자료는 다른 보고원과의 정보의 시간적 차이 가 있지만 재해 발생 후 보고원별 보완점을 발견하며 추후 보고시스템의 완결성을 추구하 는데 국민건강보험 자료는 필수적인 자료이다.

셋째, 감시자료 보고원과 지원체계 확충에 대한 필요성이 제기되었다. 마을주민대표와 국 민건강보험, 농협공제(농업인 안전공제와 농기 계 종합공제), 소방방재청, 산업재해보상보험 등 여러 경로를 통한 자료의 상호보완이 필요 하다. 그러기 위해서는 보건복지부, 농림부, 행 정자치부, 노동부의 유기적인 협조체제 구축이 필요하며 이를 위해서는 농작업재해 감시체계 의 목적과 필요성에 대한 인식을 공유하는 것 이 필요하다.

넷째, 보고체계 개선의 필요성이 제기되었다. 감시체계의 핵심이었던 마을주민대표에 의한 보고는 마을주민이 감시보고서에 작성을 하여 마을주민대표가 수거하는 방식이었다. 마을주 민대표에게 마을주민의 자료를 취합하도록 하 는 보고체계는 즉각적인 보고가 이루어지지 않고 보고의 누락이 발생할 가능성이 높아 전
체적인 농작업재해의 규모가 축소될 수 있다. 또한 보고원에 따른 다양한 보고형식으로 인 하여 자료 취득 후 정보의 처리과정에도 많은 시간이 소모되는 단점이 있다. 보고체계의 단 일화라는 측면과 신속하고 누락되지 않는 정 보의 관리라는 측면에서 농작업재해 감시체계 의 온라인 보고체계를 고려할 수 있다.

\section{3. 농작업재해 감시모델의 제시}

재해가 발생 하면 119소방서, EMS (Emergency Medical System) 및 자가용(버스) 등을 통해 이송이 이루어지고 의료기관을 통 한 치료가 이루어지며, 산업재해보상보험 또는 농협공제(농업인 안전공제 및 농기계 종합공 제)에 가입된 경우 보상이 이루어지고 재해의 발생 직후 모든 재해의 상황은 마을주민대표 를 통해 보고된다. 마을주민대표를 통한 감시 체계 자료의 취합은 전화, 팩스, 우편 및 인터 넷(홈페이지)을 통하여 이루어진다. 여기에서 누락된 자료는 소방방재청, 의료기관, 건강보 험, 농협공제, 산재보험 및 사망통계 등의 자료 를 통해 보완된다. 각 과정에서 취합된 자료를 분석하고, 분석된 자료는 지역주민과 지역농업 분야인력 및 보건의료인력에게 소식지, 이메 일, 지역방송, 신문 등을 통해 배포된다(그림 2) . 


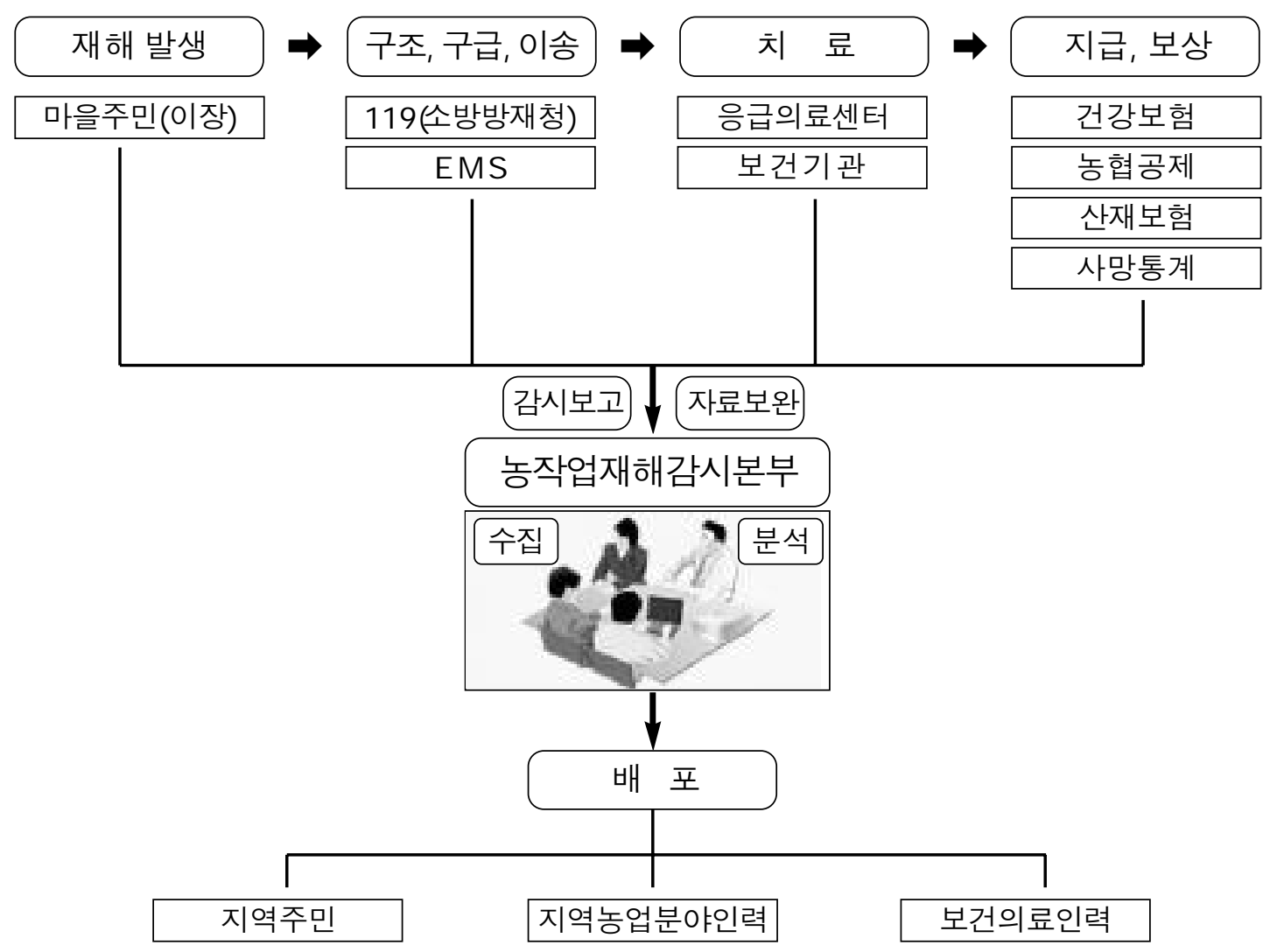

그림 2. 농작업재해 감시체계 모델개요

고 찰

우리나라는 전통적으로 농업이 중요 산업이 었으나 1960ㅕㅕㄴㄷㅐ 이후 급속한 산업발전과 도 시화로 2,3차 산업이 급속도로 성장한 반면 농 업에 종사하는 인구는 계속 감소하고 있다. 그 러나 2004년 통계청에서 시행한 농어업 총 조 사에 따르면 우리나라의 농업 세대의 인구수 는 341만 5천명으로 과거에 비해 농업이 다른 산업에 비해 가지는 상대적 중요성은 많이 감 소했으나 아직도 전 인구의 $7.1 \%$ 가 농업으로 생계를 유지하고 있어 절대적 수치로 볼 때 적은 규모의 산업이라 할 수 없대 [34] .

급격한 산업발전과 도시화는 2, 3차 산업 뿐 만 아니라 농업의 형태도 변화시켰는데 농업 종사 인구의 감소로 1 인당 경작 면적의 증가 와 농기계 보급률의 증가 등 농업의 기계화가 이루어졌고, 단위면적당 생산량을 늘리기 위하
여 농약과 화학비료의 사용이 증가하는 등의 변화를 가져왔다. 이러한 변화는 필연적으로 농민들의 건강상태에 영향을 미치게 되었으며 농업의 기계화로 인한 손상의 증가, 농약 사용 으로 인한 농약 중독 등이 건강을 위협하는 대표적인 예라 할 수 있다. 농어업의 여건 변 화에 따른 작업부담강화, 유해작업환경증가로 농업인의 직업성재해 발생이 증가하고 있으나 농작업관련 질환의 보고 및 판정사례는 극히 저조하다. 농민들의 대다수가 자영농이기 때문 에 직업성 재해관리체계의 대상이 되지 못하 며, 고용농업인의 경우에도 농부증 등 직업성 질환의 명확한 진단. 판정기준이 확립되어있 지 않고, 전문 의료 인력과 기관이 부족한 것 이 현실이다.

이번 연구는 농작업 도중 발생하는 손상 규 모를 파악하기 위하여 감시체계를 구축하고 시범운영을 통해 우리 실정에 맞는 새로운 감 
시모델을 개발하고자 하였다. 시범운영에서 마 을주민대표 보고에 의한 농작업재해율은 $3.4 \%$ 로 2004년 산업재해원인분석에 의한 농업재해 율 $1.2 \%$ 에 비해 상당히 높은 값이다[35]. 하지 만 낮은 응답률과 회상오류에 의한 바이아스 가 발생할 수 있고[36], 대다수의 자영농은 산 업재해보상을 받지 못하기 때문에 해석에 주 의를 요한다. 마을주민대표는 감시체계의 핵심 적인 보고원이지만, 보고자에 따라 보고의 질 과 양이 다양하게 나타날 수 있다. 그리고 감 시체계 자료원인 구급활동일지, 의무기록 등은 개인정보보호법 등으로 인해 자료의 접근이 어려웠다. 또한 국민건강보험, 농협공제, 소방 방재청, 산업재해보상보험 자료 등은 다양한 분야에서 각기 필요한 형태로 수집. 분석되고 있어, 재해의 원인을 구명하고 정책결정에 활 용될 수 있는 정보를 제공하는데 한계가 있다. 그러므로 자료의 신뢰성 및 정확성을 높여 다양한 자료를 감시본부가 취합하여, 각각의 특성을 고려하여 해석하는 것이 필요하며 보 다 다양한 농작업재해 감시체계 자료를 확보 하기 위해서는 다음과 같은 사항을 고려해야 할 것이다.

첫째, 환례 정의를 보완한다. 2004년도 농작 업재해 감시체계의 시범운영에서 시범지역에 정의된 환례는" 농기계(경운기, 트랙터, 콤바인 등)나 농기구(손연장, 파워연장 등)에 의해 손 상을 받는 경우 또는 작업장에서 추락/전도하 거나, 가축에게 물리는 등 농작업 도중 발생하 는 모든 농작업 손상 중 1 차 의료기관 이상에 서 진료를 받은 자"로 정의하여 다른 감시체 계를 통해 확보한 자료들과 비교 가능하도록 하였다. 그러나 의료기관 접근이 용의하지 않 거나, 환자 혹은 보호자의 무지 등으로 실제로 1 차 의료기관 이상의 진료가 필요하지만 이루 어지지 않는 경우가 있을 수 있다. 그러므로 이번 시범운영서도 재해의 규모가 저평가 되 었을 가능성이 높다. 시범운영 이후의 농작업 재해 감시체계에서는 의료기관의 진료가 필요 했지만 의료기관의 진료를 받지 않은 경우도
환례에 포함시켜 재해의 규모와 특성을 바르 게 파악할 수 있다.

둘째, 마을주민대표 중심의 보고체계를 확충 한다. 마을주민대표는 지역의 실정에 밝고 병 원 치료를 받을 정도의 손상을 입은 지역주민 에 대한 파악이 비교적 쉬운 농작업재해 감시 체계의 핵심적인 보고원이다. 농작업재해 감시 체계의 시범운영을 통하여 보고된 11건의 환 례 중 10 건이 마을주민대표를 통하여 보고되 었다. 하지만 시범운영을 통해 즉각적인 보고 가 이루어지지 않는 회상오류가 발생할 가능 성이 있으므로 주단위 또는 월단위로 마을주 민대표의 보고에 대한 확인 및 환류를 통해 빠짐이 없는 농작업재해 기록의 취합이 이루 어질 수 있도록 해야 한다.

셋째, 보고체계의 완결성을 강화한다. 재해의 발생과 동시에 이루어지는 여러 가지 과정을 통해 마을주민대표의 재해 보고 시 누락될 수 있는 자료의 완결성이 이루어진다. 먼저 재해 의 발생 후 치료 받을 수 있는 의료기관으로 의 운송단계이다. 119소방서를 통해 운송이 이 루어지면 구급활동일지를 작성하도록 되어 있 으며, 여기에는 사고의 전반적인 내용 및 이용 기관 이송 형태 등 감시체계에서 필요한 여러 정보를 포함하고 있고 소방방재청에서는 이에 대한 정보를 데이터베이스화하고 있다. 그러나 개인정보보호법 등으로 인해 자료 활용에 제 약을 받는다. 이번 시범운영에서와 같이 구급 활동일지를 개별 열람할 경우 자료의 누락이 발생할 가능성이 있으므로 소방방재청의 데이 터베이스화된 자료의 활용이 필요하며 또한 개인정보보호법의 예외사항으로 개인정보의 제공이 가능해야 하겠다. 그 외 병원구급차,

EMS(Emergency Medical System) 및 자가용 을 통한 운송이 가능하겠으나 부가적인 정보 를 얻기는 힘들다. 그리고 재해가 발생하여 의 료기관으로의 이송이 이루어지면 치료가 이루 어진다. 의료기관에는 응급의료센터, 개인의원, 2차병원 이상의 종합병원, 보건소, 보건지소가 있으며 각 기관의 의무기록은 재해의 원인 및 
기전과 재해로 인한 손상의 세부사항을 잘 기 술하고 있는 자료이다. 그러나 개인정보에 관 계된 자료를 취합한다는 것은 여러 가지 이유 로 현실적으로 정보취득이 어렵다. 마지막으로 재해의 발생 후 이송과 치료가 이루어지고 진 료비 지급의 절차가 남는다. 진료비는 진료의 대가로 의료기관에 환자가 지불하게 되는데, 거의 모든 경우에서 국민건강보험의 수급대상 이 된다. 국민건강보험으로 본인 부담금을 일 부 지급하고 나머지는 국민건강보험공단에서 의료기관에게 지불하게 된다. 진료비 중 본인 부담금의 일부는 농업인 안전공제 또는 농기 계 종합공제에 가입된 경우 보상을 받을 수 있다. 이 과정에서 농업인 안전공제 또는 농기 계 종합공제에 정보를 제공하게 되는데 그 정 보를 농업인 안전공제 또는 농기계 종합공제 에서 받을 수 있다. 의료기관이 국민건강보험 공단에 의료비를 청구하기 위해서 제공하는 정보 또한 취합 가능한 정보이나 개인정보의 보호 차원에서 제한을 받게 된다.

넷째, 건강보험 심사평가원 자료를 통한 농 작업재해의 전체적인 규모와 특성을 파악한다. 의료기관이 의료비의 청구를 위해 국민건강보 험공단에 청구한 자료는 건강보험 심사평가원 에서 의료비의 적정성 여부를 심사하여 의료 기관에 진료비를 지급하게 된다. 건강보험 심 사평가원은 개인의 치료일, 진료코드, 진료비 (본인부담금, 전체 진료비) 등의 정보를 제공할 수 있으나, 개인정보 보호차원에서 개인 아이 디와 나이를 생략한 자료를 제공할 수 있다. 이 자료에서 손상에 관계된 코드만 분석하여 농작업재해의 전체적인 규모와 특성은 파악할 수 있다.

이번 연구를 통해 감시 자료의 완결성과 상 호보완이 필요하였고,' 개인정보보호법'과 같 은 인권보호 측면의 강조로 향후 감시체계 가 동에 어려움이 있을 것으로 예상된다. 하지만 농작업재해의 예방과 관리라는 큰 목적을 달 성하기 위하여 각 기관과의 양해각서(MOU) 체결과 윤리적인 측면의 보완 그리고 부처 간
협조체계 수립이 필요하다고 할 수 있다.

최근의 의료시스템은 과거 어느 때보다 커 다란 변화를 겪고 있다. 의료공급체계는 의료 보험의 확대로 각 의뢰단계에서 얻을 수 있는 정보의 질과 양이 다르며, 특히 농촌지역의 경 우 보건진료소, 보건지소, 보건소 또는 지역 중 심병원 등으로 이어지는 체계가 감시자료 취 득원이 될 수 있다. 특히 응급의료체계가 중요 한 역할을 하게 될 농작업재해 감시체계의 경 우 각급의료기관의 응급의료센터 또는 응급실, 그리고 119 소방서의 응급환자 후송체계의 자 료가 중요한 역할을 할 것이다. 전국이 전산망 으로 연결되어 있고 의무기록 또는 환자의 수 진자료가 전산화되어 있다는 것도 의료 인프 라의 변화이다. 의료부분의 전산화는 환자의 자료를 쉽게 취득할 수 있는 장점과, 정보의 보안, 비밀 등 자료 이용 시 중요하게 고려해 야 할 사항도 있다는 것을 의미한다. 이 분야 는 공중보건 감시체계의 가장 중요한 인프라 이다. 공중보건학적으로 중요한 의미를 가지는 감염성 및 만성질환, 환경· 산업보건, 그리고 건강증진 영역의 역학 자료와 실험 및 검사자 료를 정보학의 방법과 기술을 이용하여 보건 의 실무와 연구에 적용하는 방법과 활용방안 을 강구하는데 중요한 역할을 하며, 감시체계 의 운용에 있어서는 더욱 그러하다. 국민건강 보험 수진자료는 전 국민 건강보험 가입으로 대부분의 의료행위의 중요한 정보원이 된다. 특히 1차 의료기관 이상의 모든 진료에 대한 파악이 가능하다. 따라서 건강보험 심사평가원 을 통한 국민건강보험 자료가 확보되고 손상 데이터베이스를 구축하여 분석이 가능하다면, 다른 보고원의 자료에 대한 완결성 보완이 가 능할 것으로 판단된다.

재해의 발생, 원인, 치료 및 그 결과를 모니 터링 하는 감시체계는 농작업재해의 효과적인 예방과 관리에 필수적이다. 이 감시체계는 자 료를 모으고, 분석하고 해석하여, 정보화된 결 과를 필요로 하는 이들에게 배포한다. 농작업 재해 감시체계는 다양한 분야에서 농업인을 
위한 정책과 프로그램 및 각 서비스를 기획하 고 평가하는데 필요한 정보를 정책결정자에게 제공할 뿐 아니라, 시의 적절한 정보생산자로 서의 역할을 할 것으로 기대된다.

2004년부터 질병관리본부에서는 『자살, 사고 등 국가감시체계 개발』연구를 시작으로 응급 실손상환자감시 및 입원손상환자조사와 손상 사망감시에 대한 손상감시체계를 구축하고 있 으며, 2005년 3월부터 매월' 손상감시정보'를 발간하여 전국의 16 개 권역응급의료센터에서 수집된 응급실손상환자감시 자료를 제공하고 있다. 이 정보는 전체적인 손상의 정도, 교통사 고와 자살에 의한 손상의 특징들, 그리고 소아 에서의 손상의 정도를 파악할 수 있다는 장점 이 있으나 직업분류가 없어 직업군에 대한 통 계를 생산하기 어렵고, 손상기전 분류에 대한 입력 충실도가 $70 \%$ 수준이어서 손상기전의 정확한 파악이 어렵다는 한계가 있다[37-38].

\section{요 약}

산업재해가 발생하는 원인은 기술적 원인, 교육적 원인, 관리적 원인으로 분류된다. 기술 적 원인(engineeringf) 건물, 기계장치 설계불 량, 구조. 재료의 부적합, 생산 공정의 부적당, 정비 불량 등이며 교육적 원인(education\& 안 전의식 부족, 안전 수칙 오해, 경험. 훈련 미 숙, 교육 불충분 등이다. 관리적 원인 (enforcement) 안전관리 조직 결함, 안전수칙 미제정, 작업준비 불충분, 작업지시 부적당 등 을 들 수 있다[39]. 농작업재해를 감소시키기 위해서는 기술적, 교육적 및 관리적 접근이 통 합적으로 이루어지는 것이 필요하며 이를 위 해서는 농작업재해현황(통계)에 대한 정확한 이해와 이를 토대로 한 농업인 재해에 대한 기초 자료의 확보가 가장 중요하다.

이를 위해 우리나라 실정에 맞는 농작업재 해 감시 방법론을 개발하고, 시범운영을 하였 다. 이번 시범운영은 경기도 양평군 일개 면을 대상으로 2004견 1월 1일부터 12월 31일까지 1
년 동안 농작업 도중 발생하는 손상에 대해 조사하였다. 주보고원은 마을주민대표, 응급의 료센터, 119소방서였고, 총 11건의 농작업재해 가 보고되었다. 마을주민대표가 보고한 농작업 재해율은 $3.4 \%$ 였고, 농기계손상이 대부분이었 고, 손상기전은 기계의 전복이 가장 많았다. 시 범운영을 통해 자료원의 성격을 파악하였고, 농작업재해 감시체계 자료원의 완결성 평가와 감시 자료의 신뢰성 및 정확성 확보의 필요성 이 제기되었다. 또한 감시자료 보고원과 지원 체계 확충 및 보고체계 개선에 대한 필요성이 제기되었다. 이러한 점들을 고려하여 환례 정 의를 보완하고, 마을주민대표 중심의 보고체계 를 확충하며, 보고체계의 완결성을 강화하고, 국민건강보험 자료를 통한 농작업재해의 전체 적인 규모와 특성을 파악하는 농작업재해 감 시체계 모델을 개발하였다.

효과적인 농작업재해의 예방과 관리를 위해 서 재해의 발생, 원인, 치료 및 그 결과를 모니 터링 하는 감시체계는 필수적인 시스템이다. 감시체계는 자료의 수집, 분석, 해석 및 정보교 류를 포괄적으로 수행하는 시스템을 필요로 한다. 현재 감시체계가 필요로 하는 자료들은 의료보험, 보건의료기관, 농업분야, 산재보상 등 다양한 분야에서 각기 필요한 형태로 수 집· 분석되고 있어, 재해의 원인을 구명하고 정책결정에 활용될 수 있는 정보를 제공하는 데 한계가 있다. 따라서 농작업재해 감시체계 는 여러 분야에서 별도로 이루어지고 있는 자 료의 수집, 공유, 활용 등을 포괄하는 국가적 과제로 논의되어야 한다.

\section{참고문헌}

1. Takala J. Work-related fatalities reach 2 milion annually. International Labour Organization (ILO), 2002. A vailable from: URL : http: / / www.ilo.org/ global/ A b out_the_ILO/Media_ and_public_infor mation/Press_releases/lang-- 
en/WCMS_007789/index.htm

2. 윤상용, 박동현, 이동호, 윤명환. 농업기계에 의한 재해현황과 안전대책방안. 한국산업안 전공단 산업안전보건연구원, 1999

3. Hong DY, Kim JR, Lee MS, Kang KH, $\mathrm{Ha}$ HS. A Study on the causes of farmer's disease and greenhouse disease in a rural area of Kyungnam province. Korean J Rural Med 1996; 21(2): 173193(Korean)

4. Lee W, Lim CS, Lee KS, Chang SH. Immunotoxicity among Farmers Exposed to Pesticides. Korean J Prev Med 1999; 32( 3) : 347- 354(Korean)

5. Park SK, Nam SM, Hwang GS, Park $H$, Chung SE, Kim EJ, Kim HS, Sun $B K$, Yang $Y J$, Lee EH, Cho HD. A Study on the Factors affecting Pesticide Poisoning of a Rural Population. Korean J Occup Environ Med 1999; 11(2): 196205( Korean)

6. Lee GM, Min SY, Jung MH. A Study on the Health Effects of Pesticide Exposure among Farmers. Korean J Rural Med 2000; 25(2) : 245- 264(Korean)

7. Lim HS. Health Hazards of Farming and Fishing in Korea. Korean J Rural Med 2002; 27( 1) : 197-215(Korean)

8. Sull JW, Yi SW, Sohn TY, Jee SH, Nam CM, Ohrr H. Pesticides and Cancer Incidence: The Kangwha Cohort Study. Korean J Prev Med 2002; 35(1): 24-32 (Korean)

9. 노동부. 노동백서. 2005

10. Kang CY. An estimation of economic and social cost of agricultural machinery accidents in Korea. Korean rural economic review 2004; 27(2): 1- 20 (Korean)

11. Gunderson P, Gerberich S, Gibson R,
A dlis S, Carr P, Erdman A, Elkington $\mathrm{J}$, French R, Melton J, True J. Injury surveillance in agriculture. $A m \mathrm{~J}$ Ind Med 1990; 18(2) : 169- 178

12. Nordstrom DL, Layde PM, Olson KA, Stueland D, Brand L, Follen MA. Incidence of farm-work-related acute injury in a defined population. $A m \mathrm{~J}$ Ind Med 1995; 28(4) : 551- 564

13. Browning SR, Truszczynska $H$, Reed D, McKnight $\mathrm{RH}$. A gricultural injuries among older Kentucky farmers: The Farm Family Health and Hazard Surveillance Study. Am J Ind Med 1998; 33( 4) : 341- 353

14. Lewis MQ, Sprince NL, Burmeister LF, Whitten PS, Torner JC, Zwerling C. Work-related injuries among lowa farm operators: an analysis of the lowa Farm Family Health and Hazard Surveillance Project. Am J Ind Med 1998; 33(5): 510-517

15. Hartling L, Pickett W, Guernsey JR, A lberg $N$. Injuries associated with the farm harvest in Canada. CMAJ 1998; 158( 11) : 1493- 1496

16. Lyman S, McGwin G J r, Enochs R, Roseman JM. History of agricultural injury among farmers in Alabama and Mississippi: prevalence, characteristics, and associated factors. A $\mathrm{m} J$ Ind $M$ ed 1999; 35( 5) : 499- 510

17. Pickett W, Hartling L, Brison RJ, Guernsey JR. Fatal work-related farm injuries in Canada, 1991- 1995. Canadian A gricultural Injury Surveillance Program. CMAJ 1999; 160(13): 18431848

18. McGwin G Jr, Enochs R, Roseman JM. Increased risk of agricultural injury 
among A frican-A merican farm workers from A labama and Mississippi. A $m$ J Epidemiol 2000; 152 (7) : 640-650

19. McGwin G Jr, Scotten $S$, A ranas A, Enochs R, Roseman JM. The impact of agricultural injury on farm owners and workers in A labama and Mississippi. A m J Ind Med 2000; 37( 4) : 374- 381

20. Rasmussen $\mathrm{K}$, Carstensen $\mathrm{O}$, Lauritsen $J M$. Incidence of unintentional injuries in farming based on one year of weekly registration in Danish farms. A $m$ J Ind Med 2000; 38( 1) : 82- 89

21. McCurdy SA, Carroll DJ. A gricultural Injury. Am J Ind Med 2000; 38(4) : 463480

22. Park H, Sprince NL, Lewis MQ, Burmeister LF, Whitten PS, Zwerling C. Risk factors for work-related injury among male farmers in lowa: a prospective cohort study. Occup Environ med 2001; 43( 6) : 542-547

23. Horsburgh S, Feyer AM, Langley JD. $F$ atal work related injuries in agricultural production and services to agriculture sectors of New Zealand, 1985-94. Occup Environ Med 2001; 58( 8) : 489- 495

24. Mull LD, Engel LS, Outterson B, Zahm $\mathrm{SH}$. National farmworker database: establishing a farmworker cohort for epidemiologic research. $A m$ J Ind $M e d$ 2001; 40 (5) : 612- 618

25. Pickett W, Hartling L, Dimich-Ward H, Guernsey JR, Hagel L, V oaklander DC, Brison RJ. Surveillance of hospitalized farm injuries in Canada. Inj Prev 2001; 7(2) : 123- 128

26. McCurdy SA, Samuels SJ, Carroll DJ, Beaumont JJ, Morrin LA. A gricultural injury in California migrant Hispanic farm workers. Am J Ind Med 2003; 44( 3) : 225- 235

27. Dimich-Ward H, Guernsey JR, Pickett W, Rennie D, Hartling L, Brison RJ. Gender differences in the occurrence of farm related injuries. Occup Environ Med 2004; 61 (1) : 52- 6

28. Lindsay S, Selvaraj S, Macdonald JW, Godden DJ. Injuries to Scottish farmers while tagging and clipping cattle: a cross-sectional survey. Occup Med ( L ond) 2004; 54( 2) : 86-91

29. Saar PE, Dimich-Ward H, Kelly KD, Voaklander DC. Farm injuries and fatalities in British Columbia, 1990-2000. Can J Public Health 2006; 97( 2) : 100- 104 30. Kim BS, Chon HJ, Cha IJ. Farmer's Syndrome and The Accidents Due to A gricultural Machines of Some Rural Residents. Korean J Rural Med 1993; 18( 1) : 93- 102( Korean)

31. Son $M H$, Shin JH, Lee $M H, M$ oon $G$, Sohn SJ, Choi JS, Kim BW. A Study on Farming Tool-Machinery Injuries in Chonnam Province. Korean I Rural Med 1993; 18(2) : 121- 130(Korean)

32. Kim BS, Chon HJ. A Study for Injuries due to A gricultural Machines in Kyeongsangnam Province. Korean J Rural Med 1995; 20 (1) : 15-23(Korean)

33. Kim D, Jung C. A ccident and disease related to agriculture in a rural Korea. Korean J Rural Med 19998; 23(1): 3948(Korean)

34. 농림부. 농림통계연보. 2005

35. 노동부. 2004년도 산업재해 현황분석. 2005

36. Solomon C, Poole J, Palmer KT, Coggon D. Non-fatal occupational injuries in British agriculture. Occup 
Environ Med 2007; 64( 3) : 150- 154

37. 질병관리본부. 손상감시정보. 2005년 12월, 제 1 권 제 7 호

38. 질병관리본부. 손상감시정보. 2006년 1월, 제 2 권 제 1 호

39. Rasmussen J. The role of error in organizing behaviour. 1990. Qual Saf Health Care 2003; 12( 5) : 377- 385 